\title{
Bir Yeniden Yazım Örneği Olarak Frankenstein
}

\section{Frankenstein As A Case of Rewriting}

\author{
Merve Sevtap Süren ${ }^{1}$ (], Arsun Uras Y ${ }_{1} \operatorname{lmaz}^{2}$ (1)
}

IIstanbul Üniversitesi, Sosyal Bilimler Enstitüsü, Çeviribilim Doktora Programı, İstanbul, Türkiye

${ }^{2}$ Istanbul Üniversitesi, Edebiyat Fakültesi, Çeviribilim Bölümü, İstanbul, Türkiye

ORCID: M.S.S. 0000-0001-6888-391X; A.U.Y. 0000-0001-8266-2822

Sorumlu yazar/Corresponding author: Merve Sevtap Süren (Doktora Öğrencisi), İstanbul Üniversitesi, Sosyal Bilimler Enstitüsü, Çeviribilim Anabilim Dalı, İstanbul, Türkiye E-posta: ilginmerve@gmail.com

Başvuru/Submitted: 14.10.2019 Kabul/Accepted: 20.06 .2020

Atıf/Citation: Suren, M. S. ve Uras-Yilmaz, A. (2020). Bir yeniden yazım örneği olarak Frankenstein. Istanbul Üniversitesi Çeviribilim Dergisi - Istanbul University Journal of Translation Studies 12, (2020), 29-52.

https://doi.org/10.26650/iujts.2020.12.0003

\section{ÖZ}

Yeniden yazım farklı alanlarda"metinlerarasılık" (intertextuality), "metinselaşkınlık" (hypertextuality), "uyarlama” (adaptation) gibi kavramlarla ilişkilendirilerek ele alındığı kadar, çeviribilim alanında da incelenen ve daha çok "dillerarası çeviri" (interlingual translation) bağlamında değerlendirilen bir kavramdır. Yeniden yazımı tüm bu farklı boyutlarıyla çeviribilim alanında irdelemeyi amaçlayan bu çalışmada beş farklı yeniden yazım örneği sunması bakımından bütünce olarak Ingiliz yazar Mary Shelley'nin Frankenstein ya da Modern Prometheus eserinden yararlanılmıştır. Bu bütüncenin sağladığı farklı yeniden yazım biçimlerine değinildikten sonra, ilk kez 1818'de basılan Frankenstein'ın kendi yazarı tarafından yeniden yazılmış 1831 versiyonu André Lefevere'in "yeniden yazım" üzerine yaptığı çalışmalar ışığında "ideolojik" bir yeniden yazım olarak değerlendirilmiştir. Bu ideolojik yeniden yazımın izleri önce yazarın biyografisinde sürülmüş, daha sonra Frankenstein'ın 1818 ve 1831 metinleri karşılaştırmalı olarak incelenmiştir. Bütüncedeki metinsel ve söylemsel verilerden yola çıkarak tematik açıklamalarla yeniden yazımın ardındaki bireysel ve toplumsal ideolojiyi betimleyen bir çözümleme gerçekleştirilmiştir. Bu incelemenin sonucunda Frankenstein'ın 1831'deki yeniden yazımı, Mary Shelley'nin "yazar imgesinin yeniden yazımı" olarak ele alınmıştır. Bir metnin aynı yazar tarafından yeniden yazıldığı örneklerde bir imge kurgulama aracı ya da bir ideolojileştirme işlemi olarak görülebilecek yeniden yazımlar "yazarın imgesinin yeniden yazımı" olarak değerlendirilmiştir.

Anahtar kelimeler: Yeniden yazım, Frankenstein, Metinlerarasılık, İdeoloji, İmge

\section{ABSTRACT}

"Rewriting" has been associated with different concepts such as "intertextuality", "hypertextuality" and "adaptation" in various fields of study whereas in Translation Studies it has mostly been viewed within the context of "interlingual translation". The purpose of this article is to explore the concept and different dimensions of "rewriting" within the scope of Translation Studies. For this purpose, the novel Frankenstein; or, The Modern Prometheus by English author Mary Shelley has been selected as the corpus because it presents five different forms of rewriting in itself. After referring to these different examples of rewriting, the rewritten 1831 version of Frankenstein, which was first published in 1818 , will be analyzed as an "ideological" rewriting, in light of the views of André Lefevere on the concept. The hints of this ideological rewriting will be traced in the author's biography, and then 1818 and 1831 versions of the text will be studied comparatively. Making 
use of this textual and discursive data and providing thematic commentaries, our descriptive study will attempt to reveal the personal and social ideology behind the rewriting. As a result of this descriptive study, the rewritten 1831 version of Frankenstein will be reckoned as Mary Shelley's rewriting of her own authorial image. In the examples where the texts are rewritten by their own authors, these rewritings might be utilized as "image construction tools" and/or "ideologization processes", thus we conclude that they should be viewed as "the rewritings of the authorial images".

Keywords: Rewriting, Frankenstein, Intertextuality, Ideology, Image

\section{EXTENDED ABSTRACT}

"Rewriting" has been associated with different concepts such as "intertextuality", "hypertextuality" and "adaptation" in various fields of study, whereas in Translation Studies it has mostly been viewed within the context of "interlingual translation". The purpose of this article is to explore the concept and different dimensions of "rewriting" within the scope of Translation Studies.

For this purpose, the novel Frankenstein; or, The Modern Prometheus by English author Mary Shelley has been selected as the corpus because it presents five different examples of rewriting in itself. First of all, in light of the notions that there is no such thing as "the original" and all texts are derived from previously written texts, the 1818 version of Frankenstein will be viewed as "writing as rewriting" because the author is believed to have rewritten the Prometheus myth, Milton's Paradise Lost and Coleridge's The Rime of the Ancient Mariner in the 1818 Frankenstein. Secondly, Shelley rewrote the 1818 text in 1831, which will be viewed as "editing as rewriting" in this study. Although she claimed that she had "changed no part of the story" and only "mended the language," "leaving the core and substance untouched" in the introduction she penned for the 1831 edition, there are substantial differences between these two texts that go beyond the language. Thirdly, Frankenstein was rewritten by Peter Ackroyd in his 2008 book The Casebook of Victor Frankenstein, in which he not only used the plot and the characters of Frankenstein but also included Mary Shelley and her husband Percy Bysshe Shelley in the fictional world of the novel. This dimension of rewriting will be viewed as "hypertextuality as rewriting". Fourthly, Frankenstein has been translated into many languages since its first publication in 1818. There are almost thirty Turkish versions of Frankenstein, which means there are also that many texts to be studied from the point of "translation as rewriting". And lastly, Shelley's Frankenstein has been adapted to various movies, plays, comics and video games, each of which can be studied as an example of rewriting since we view "adaptation as rewriting".

After referring to these different dimensions of rewriting, the rewritten 1831 version of Frankenstein, which was first published in 1818, will be analyzed as an "ideological" rewriting. To this end, we will be adopting the views of André Lefevere, who claimed that any text produced on the basis of another has the intention of adapting that first text to a certain ideology or to a certain poetics, and usually to both. The hints of this ideological rewriting will 
be traced in the author's biography, since Shelley can be considered to have wavered between the open-minded and liberating views of her parents and husband, and the conservative values of the society. Thus it would not be incorrect to assume that this dilemma was reflected on her writing as well. Following this biographical commentary, the 1818 and 1831 versions of Frankenstein will be studied comparatively. Making use of this textual and discursive data and providing thematic commentaries, our descriptive study will attempt to reveal the personal and social ideology behind the rewriting. As a result of this descriptive study, the rewritten 1831 version of Frankenstein will be reckoned as Mary Shelley's rewriting of her own authorial image. In the examples where the texts are rewritten by their own authors, these rewritings might be utilized as "image construction tools" and/or "ideologization processes", thus we conclude that they should be viewed as "the rewritings of the authorial images". 


\section{Giriş}

Yeniden yazım (rewriting) kavramı felsefe, edebiyat, metinlerarasılık, yapısalcılık sonrası ve çeviri gibi farklı bağlamlarda, farklı biçimlerde ele alınan ve her birinde hem birbirinden farklı, hem de özü itibariyle benzer anlamlar taşıyabilen bir kavramdır. Theo Hermans'a göre, "[y]eniden yazım çeviri, eleştiri, inceleme, özetleme, çocuklar için uyarlama, antoloji haline getirme, çizgi romana ya da televizyon filmine dönüştürme vb. işlemleri, kısacası bir metnin ister aynı dilde, ister farklı bir dilde, isterse farklı bir ortamda herhangi bir biçimde işlenmesini kapsar"’1 (2009: 127). Hermans'ın yeniden yazımın çeşitli boyutlarına değindiği bu geniş kapsamlı tanımdaki "ister aynı dilde, ister farklı bir dilde, isterse farklı bir ortamda" ifadesi Roman Jakobson'un ortaya koyduğu (2008: 62) üç çeviri türünü, “diliçi çeviri”, "dillerarası çeviri” ve "göstergelerarası çeviri”" kavramlarını çağrıştırmaktadır. Çeviri ve yeniden yazım kavramları düşünüldüğünde ilk akla gelen isimlerden olan André Lefevere'in "yeniden yazım terimi, 'çeviri', 'uyarlama', ‘öykünme’ gibi çeşitli yeniden yazma biçimleri arasında kesin sınırlar çizme zorunluluğunu ortadan kaldırır" (1992: 47) yaklaşımını göz önünde bulundurarak farklı yazma biçimleri, çeviri türleri ve yeniden yazım arasındaki ilişkiyi daha geniş bağlamda sorgulayabiliriz. Bu bakış açısından hareketle yeniden yazım biçimlerini ve bu yeniden yazma biçimlerinin çeviribilim alanında daha geniş bir kapsamda irdelenip irdelenemeyeceğini sorgulayan bu çalışmada bütünce olarak Frankenstein ya da Modern Prometheus adlı eserin aşağıda başlıklar halinde değinilecek farklı biçimlerdeki yeniden yazımları kullanılacaktır.

\section{Frankenstein ve "Yeniden Yazım"}

Frankenstein ya da Modern Prometheus veya daha yaygın ismiyle Frankenstein, İngiliz yazar Mary Shelley tarafından yazılmıştır. Roman, Kaptan Robert Walton'un kız kardeşi Margaret Walton Saville'e yazdığı mektuplarla başlar ve biter; Victor Frankenstein'ın hikâyesini anlatmak için çerçeve olarak Walton'ın mektuplarının kullanılması, çerçeve anlatı tekniğiyle yazılmış bu romana "mektup roman” özelliği de katar. Kitapta birinci ağızdan üç anlatı yer alır: Walton'ın kız kardeşine yazdığı mektuplardaki anlatısı, Frankenstein'ın anlatısı ve canavarın anlatısı. Frankenstein romanının, çerçeve anlatı tekniğiyle yazılmış olması, bireyin yalnızlığını çağrıştıran ürkütücü ve karanlık ortamlarda geçiyor olması, bilimin karanlık yüzü, metafizik, mistisizm, tanrıcılık oynama gibi temalara değiniyor olması bakımından gotik roman özellikleri taşırken; aşk, ölüm, tabiat gibi konuları ele almasından ve yazıldığı dönemden ötürü de romantizm akımının izlerini taşıdığı söylenebilir.

Romanda, ölümsüzlüğe ulaşmayı amaçlayan Victor Frankenstein hayatın sırrını keşfeder ve bir ucube yaratır; fakat kendi yaratısından tiksinip uzaklaşır. Ancak yarattığı canavar onun peşini bırakmaz. Özünde iyi kalpli olsa da, hissettiği sevgisizlik ve yalnızlıktan ötürü yaratıcısına ve onun sevdiklerine zarar verir. Tek isteği kendisi gibi bir eşe sahip olmaktır. Yaratıcısı onu bu isteğinden mahrum edince ondan intikam almaya çalışır ve işler kontrol edilemez bir boyuta ulaşır.

1 Aksi belirtilmediği sürece alıntıların çevirisi tarafımızca yapılmıştır. 
Frankenstein, edebiyat ve popüler kültürde romandan öyküye, tiyatro oyunundan sinema filmine, çizgi romandan bilgisayar oyunlarına kadar pek çok başka esere de ilham kaynağ olmuştur; farklı biçimlerde birçok defa üretilmiş olması bakımından yeniden yazım kavramının farklı biçimlerini incelemeyi amaçlayan bu çalışma için uygun bir bütünce olacağını düşünüyoruz. Bu geniş kapsamlı bütüncede, çeşitli kaynaklardan beslenen yazarın metni “yeniden” yazması bağlamında, ilk kez 1818'de yayımlanan Frankenstein'ın ilk baskısı; yazarın kendi metnini yeniden yazması bağlamında kitabın yazarı tarafından yeniden yazılan 1831 basımı; farklı bir yazarın metni yeniden yazması bağlamında Peter Ackroyd'un Shelley'nin eserinden yola çıkarak yazdığı The Casebook of Victor Frankenstein adlı kitap; metnin başka bir dilde yeniden yazılması bağlamında metnin Türkçe çevirisi ve metnin başka bir gösterge türüne dönüş̧ürülerek yeniden yazılması bağlamında ise "Victor Frankenstein" adlı film uyarlaması değerlendirilecektir. Özetle, Frankenstein romanının tek başına sunduğu yeniden yazım biçimleri beş başlık altında toplanacak ve tartışılacaktır. Ancak, bu çalışma özellikle Frankenstein romanının iki farklı dönemde (1818 ve 1831) aynı yazar tarafından aynı dilde yeniden yazılmış iki metnin "Bir metnin aynı yazar tarafından yeniden yazımı" başlı̆̆ı altında yorumlanması ve değerlendirilmesi araştırma konumuzu oluşturacaktır.

\subsection{Bir Metnin Mevcut Metinlerin Türevi Olarak Yeniden Yazımı}

Julia Kristeva (1980) ve Roland Barthes'ın (1981) "metinlerarasılık," Gérard Genette'in (1997) ise "metinselaşkınlık" kavramları çerçevesinde, yazınsal metinlerin daha önce yazılmış metinlerden ayrı düşünülemeyeceğini öne sürerler. Kubilây Aktulum da bu görüşlere değindiği Metinlerarası İlişkiler adlı çalışmasında, her metnin eski metinlerden parçaların bir araya getirilmesiyle oluştuğundan söz etmiştir (2000: 17-18). Farklı biçimlerde ifade edilen bu yaklaşım bir tür yeniden yazım olarak değerlendirilebilir. Lefevere'den ödünç aldığ "yeniden yazım" kavramını sömürgecilik sonrası yaklaşımla ele alan Maria Tymoczko’ya göre de, "her yazı, yeniden yazımdır," çünkü “her edebiyat eseri, tıpkı çeviri gibi, daha önceki metinlere dayanır: Her ikisi de 'özgün anlamsal birlikler' (original semantic unity) değil, 'türev ve heterojen' [metinler]dir” (1999: 41). Buna göre, yazarın kurguladığı metin, anlamını bir bütün, bir öz olarak yalnızca kendi içinde barındırmaz, başka metinlerden oluşan bir bütünün içinden çıkar; dolayısıyla anlam tamamlanmış değil, üretim hâlindedir, yani her metin türevdir. Ayrıca tek değil, çoğul anlamlara yol açtığı için de heterojendir. "Yazmak, yeniden yazmaktır. Her yazı işi bir kolaj, yorum ve alıntıdır" (Aktulum 2000:165). Gotik roman ve romantizm akımının izlerini taşıyan Frankenstein doğrudan adıyla mitolojik Prometheus efsanesine gönderme yapmaktadır. Romanda Victor Frankenstein tıpkı Prometheus gibi insanlığa hizmet etmek amacıyla Tanrı'ya karşı gelmektedir. Victor Frankenstein'ın elleriyle yarattığı canavarın dünyaya gelişinden sonra yaşadığı manevi işkence ile Prometheus'un hikâyesi de benzerlik gösterir. Ayrıca bir yaradılış hikâyesi olması sebebiyle John Milton'ın Kayıp Cennet; ele aldığı ilim ve kimsesizlik gibi temalar bakımından ise Samuel Taylor Coleridge'in Yaşlı Gemici eserlerinin 
etkisi romanda açıç̧a hissedilmektedir. Bu anlamda Mary Shelley’nin Frankenstein'da bu metinleri yeniden yazdı̆̆ı söylenebilir.

\subsection{Bir Metnin Aynı Yazar Tarafindan Yeniden Yazımı}

Yazarın kendi metnini yeniden yazması, yani yazılmış bir metnin yeni bir versiyonu da yeniden yazım olarak tanımlanmaktadır. "Bir yazar, düzeltmek, derinleştirmek vb. amaçlarla kendi yapitlarından birini de yeniden yazabilir” (Aktulum 2000: 236). Esra Birkan Baydan'ın "Editing as rewriting" başlıklı makalesinde belirttiği gibi (2011:56), Lefevere'in yaklaşımı sayesinde yeniden yazım kavramı, editöryal uygulamaların da çeviribilim kapsamında ele alınabilir hale gelmesini sağlamıştır. Araştırmamızın bütüncesini oluşturan Frankenstein, Mary Shelley’nin kendi yazdığı metin üzerinde yaptığı çeşitli değişikliklerle 31 Ekim 1831 tarihinde yeniden yazılmış ve basılmıştır. Shelley metnin 1831 basımına yazdığı önsözde metinde yalnızca biçemsel değişiklikler yaptığını, hikâyenin hiçbir kısmını değiştirmediğini, yeni bir fikir ya da olay eklemediğini, yalnızca dilin anlatıyı bozacak kadar "yavan” (bald) kaldığı kısımları “onardığını" (mended) ifade ettiyse de iki metin karşılaştırmalı incelendiğinde Shelley'nin metinde dilsel ve biçemsel değişikliklerden ziyade metnin içeriğini ve alımlanmasını etkileyecek türden önemli değişiklikler yaptığı görülmektedir. Bu bağlamda ilk metnin metinsel/editöryal açıdan olduğu kadar ideolojik açıdan da yeniden yazıldığı söylenebilir.

\subsection{Bir Metnin Başka Bir Yazar Tarafından Yeniden Yazımı}

Kubilay Aktulum yeniden yazımı, "hangi türden olursa olsun, önceki bir metnin, onu taklit eden, dönüştüren, açık ya da kapalı bir biçimde ona gönderen bir başka metinde yinelenmesi" olarak tanımlamıştır (2000:236). Aktulum, metinlerarasılığın bir yeniden yazma işlemi olarak görülebileceğini söyler: "Bir yazar başka bir yazarın metninden parçaları kendi metninin bağlamında kaynaştırarak yeniden-yazar" (a.g.e.:17). İngiliz biyografi, roman ve eleştiri yazarı Peter Ackroyd, 2008 yılında The Casebook of Victor Frankenstein adıyla basılan kitabında Shelley'nin kanonik eseri Frankenstein 'ı yeniden yazmıştır. Ackroyd yeniden yazdığı metinde hem Shelley'nin eserindeki olay örgüsünü ve karakterleri kullanmış, hem de Shelley’nin kendisiyle birlikte hayatındaki kimi gerçek olayları ve kişileri de romanın kurmaca dünyasına dahil etmiştir. Bu anlamda Ackroyd'un oldukça ilgi çekici bir yeniden yazıma imza attığı görülmektedir.

\subsection{Bir Metnin Farklı Bir Dilde Yeniden Yazımı}

Çalışmalarında yeniden yazım kavramına da değinen çeviribilim araştırmacısı ve çevirmen Lawrence Venuti’ye göre, “çevirmen kaynak metin yazarının dublörü ya da vantriloğu değil, kaynak metni başka bir dil ve kültürde, hatta çoğu zaman başka bir dönemde başka bir kitlenin hoşuna gidecek şekilde yeniden yazan becerikli bir taklitçidir” (2012: 109). Venuti'nin bu yaklaşımı, Lefevere ve Tymoczko gibi onun da çeviriyi bir tür yeniden yazım olarak değerlendirdiğini göstermektedir. Venuti çeviriyi "çifte yazım”, "yabancı metnin alıcı kültürün 
değerlerine göre yeniden yazımı" olarak görür (2008: 276). Bu açıklamaya göre çeviri, kaynak kültürde yazılmış kaynak metnin erek dilde yeniden yazılmasıdır. Venuti yeniden yazım eylemini daha çok çevirmenin erek ya da kaynak edebiyat dizgesini odak noktası olarak seçmesi ve bu seçime göre kaynak metni yerlileştirmesi ya da yabancılaştırması bağlamında ele alır. Bu bağlamda, erek dilde yeniden yaratılmış olan çeviri metin, yerlileştirilmiş ya da yabancılaştırılmış olması bakımından erek kültürün edebiyat dizgesinde görünmezlik ya da görünürlük kazanır. Frankenstein metni İş Bankası Kültür Yayınları, Can Yayınları, İletişım Yayınları gibi seçkin yayınevleri başta olmak üzere, otuza yakın yayınevi tarafından Türkçeye çevrilmiş, yani Türkçede yeniden yazılmıştır. Bu çevirilerin çoğunda kaynak metin olarak 1831 versiyonu kullanılsa da, 1818 versiyonunu kaynak metin kabul edenler de vardır. Türkçe çeviriler kaynak metinleriyle karşılaştırmalı olarak incelendiği takdirde çevirmenlerin bu metinleri nasıl yeniden yazdıkları görülebilir.

\subsection{Bir Metnin Bir Bașka Gösterge Türünde Yeniden Yazımı}

Roman Jakobson'a göre, “Dilsel bir göstergeyi yorumlamak için, onun aynı dilin başka göstergelerine, başka bir dile ya da dilsel olmayan bir simgeler dizgesine çevrilmesine göre, üç yol seçeriz". Bunlar, "diliçi çeviri”, “dillerarası çeviri” ve "göstergelerarası çeviri”dir (2008:62). Buna göre, dilsel göstergelerin dilsel olmayan göstergeler aracılığıyla yorumlanması göstergelerarası çeviri kapsamına girer. Dilsel bir gösterge sistemine sahip yazılı bir metni ses, mimik, müzik gibi görsel ve işitsel göstergelerle aktarmak, yani dilsel göstergeleri dilsel olmayan göstergelerle yeniden yazmak bu türe örnektir. Nitekim Lefevere de Translation, Rewriting, and the Manipulation of Literary Fame adlı kitabında film ve televizyon uyarlamalarından "diğer yeniden yazım türleri” olarak söz etmiş, ancak kendi uzmanlık alanına girmediği düşüncesiyle detaylı olarak incelememiştir (1992:9). Frankenstein metni gerek kaynak kültürde gerekse erek kültürde sinema, tiyatro, animasyon, çizgi roman vb. farklı gösterge türlerine uyarlanmıştır. 2015 yapımı Victor Frankenstein adlı film uyarlamasında hikâye, Victor Frankenstein'ın asistanı Igor'un gözünden anlatılarak yeniden yazılmıştır. Bu bakış açısının ilginç yanı, Igor karakterinin Mary Shelley’nin yazdığı metinlerde yer almamasıdır. Kambur ve deforme görünümlü laboratuar asistanı Igor karakteri, korku filmleri ve korku filmi parodilerinde Kont Drakula ve Viktor Frankenstein gibi gotik karakterlerin asistanlığını yapar. Bu bağlamda 2015 uyarlamasında Frankenstein metninin hem başka bir gösterge türüne uyarlanarak hem de metinde yer almayan bir karakterin gözünden anlatılarak yeniden yazıldığı söylenebilir.

Sonuç olarak, Frankenstein eseri yeniden yazım kavramının çeviribilim bağlamında daha geniş anlamda sorgulanması adına son derece verimli bir bütünce sağlamaktadır. Eserin ilk yayımlandığı 1818 yılından bu yana yaşadığı ve yukarıda beş başlık altında topladığımız yeniden yazım serüveni bu alanda çeşitli araştırmalara konu olabilir. Bu çalışmada ise Frankenstein metni ikinci başlık, yani "Bir metnin aynı yazar tarafından yeniden yazımı" kapsamında metin örneklerinden hareketle incelenecektir. 


\section{2. "Yeniden Yazan" Mary Shelley}

Yeniden yazım kavramı üzerine düşünen ve çeviriyi “özgün metnin yeniden yazımı” (1992: vii) olarak tanımlayarak her çeviriyi birer yeniden yazım kabul eden Lefevere'e göre, ister çeviri, antoloji, eleştiri, isterse yeni bir edisyon, hangi türden yeniden yazım söz konusu olursa olsun, yeniden yazanlar üzerinde çalıştıkları orijinal metinleri, içinde yaşadıkları çağın baskın ideolojik ve poetolojik akımlarına uygun düşecek biçimde, bir ölçüde uyarlar ve manipüle ederler $^{2}$ (a.g.e.: 8). Lefevere "düzeltme"yi de çeviri, tarihyazımı, antoloji, eleştiri gibi yeniden yazım türleri arasında saymaktadır (a.g.e.: 9). Translation, Rewriting, and the Manipulation of Literary Fame adlı kitabının on ikinci bölümünde “Düzeltme” başlığı altında Georg Büchner'in Dantons Tod (Danton'un Ölümü) adlı oyununun, biri ideolojik diğeri poetolojik sebeplerden ötürü iki farklı kişi tarafından düzelti sürecinden geçirilmiş iki farklı edisyonunu yeniden yazım bağlamında incelemiştir. Bu incelemenin sonucunda metnin hangi açılardan nasıl yeniden yazıldığını ortaya koymuştur (a.g.e.: 150-160). Aynı kitabın “Translation: Ideology” (Çeviri: İdeoloji) başlıklı beşinci bölümünde ise, Anne Frank'in, ölümünden sonra Dagboeken van Anne Frank (Anne Frank' in Hatıra Defteri) adıyla basılan günlüklerini, yayımlanma ihtimali ortaya çıktığında yeniden yazmaya başladığını söyler. Lefevere, Frank'in orijinal günlüğündeki girdileri kişisel ve yazınsal amaçlarla yeniden yazmasını "auto-editing" (oto-düzelti) olarak adlandırmıştır (a.g.e.: 60). Lefevere'in yeniden yazım kavramına getirdiği bu yaklaşımlardan ve söz konusu incelemelerden ilhamla, Mary Shelley'nin Frankenstein'ın 1831 basımı için metnin 1818'de yayımlanan ilk hâli üzerinde yaptığı değişiklikleri “yeniden yazım” kavramı 1şığında değerlendirmek çalışmamızın kapsamını oluşturmaktadır.

Mary Shelley'nin Frankenstein'1 ilk kez 1 Ocak 1818 tarihinde Frankenstein; or, The Modern Prometheus adıyla 23 bölümden oluşan 3 cilt halinde anonim olarak yayımlanmıştır (Robinson, 2016:15). Yazarlığın kadınlar için çok da uygun bir meslek olarak görülmediği bir çağda bulundukları gerekçesiyle, eserin 1818 yılında Londra'da yapılan ilk baskısında yazarın adına yer verilmemiştir. Kitabın ikinci basımı 11 Ağustos 1823 yılında yapılmıştır. İlk basımda üç cilt halindeki metin, ikinci basımda Shelley’nin babası yazar William Godwin tarafından yeniden düzenlenip iki cilt haline getirilmiştir. E. B. Murray, "Changes in the 1823 Edition of Frankenstein" başlıklı makalesinde, 1823 basımında Godwin tarafından yapılan toplam 114 değişikliği sıralamıştır (1981: 320-323). Godwin metin üzerinde büyük ölçüde sözcük düzeyinde, daha çok redaksiyon olarak tanımlayabileceğimiz değişiklikler yapmıştır. Çoğu kaynakta metnin 1818 versiyonunu kullandığı söylenmesine rağmen, Mary Shelley, Frankenstein metnini 1831 'de yeniden yazarken, babası tarafından redakte edilmiş metni baz almıştır (a.g.y.: 323). 1823 basımı, "Mary Wollstonecraft Shelley” adının metnin yazarı olarak kitapta ilk kez yer aldığı basım olmasıyla da önem taşımaktadır (Robinson, 2016:20).

2 "Whether they produce translations, literary histories or their more compact spin-offs, reference works, anthologies, criticism, or editions, rewriters adapt, manipulate the originals they work with to some extent, usually to make them fit in with the dominant, or one of the dominant ideological and poetological currents of their time." (Lefevere, 1992: 8). 
Frankenstein'ın üçüncü ve “gözden geçirilmiş” basımı ise 31 Ekim 1831 tarihinde 24 bölümlük tek cilt halinde basılmıştır (a.g.y.: 21). Shelley bu basımda (1823'te babası tarafindan redakte edilmiş) 1818 metnini bizzat gözden geçirip önemli değişikliklerle “yeniden yazmıştır”. Bu bağlamda Mary Shelley’nin ilk metni yeniden yazmasının altında yatan nedenleri, yani şahsi “ideoloji”si ve/veya "poetika"sındaki değişimin olası sebeplerini (yeniden) yazarın yaşam öyküsünde arayacak ve 1818 metninde yaptığı değişiklikleri bu bakış açısıyla yorumlayacağız.

\subsection{Frankenstein'ın Yeniden Yazımında Shelley'nin Yaşam Öyküsünün Rolü}

Mary Shelley -tam adiyla Mary Wollstonecraft Godwin Shelley-1797'de Londra'da William Godwin ve Mary Wollstonecraft'ın kızları olarak dünyaya gelmiştir. Shelley'nin babası William Godwin, radikal siyasal görüşleriyle tanınan bir şair, gazeteci, politika yazarı ve fillozof; annesi Mary Wollstonecraft ise Kadın Haklarının Gerekçelendirilmesi adlı kitabı kaleme alan feminist bir yazar ve dönemin önemli kadın hakları savunucularındandır. Wollstonecraft doğumdan birkaç gün sonra hayatını kaybettiği için Mary annesiz büyüse de hatırasını kitaplarını okuyup onu örnek alarak sürdürür. Annesiyle babasının önemli birer yazar olmasının yanı sıra Samuel Taylor Coleridge gibi dönemin önemli şair ve yazarlarının sık sık ziyaret ettiği bir ev ortamında yetişen Mary, yazmaya küçük yaşlarda başlar.

Mary Shelley bulunduğu aile ortamı ve sosyal çevre ile içinde yaşadığı dönemin kendisine bir şekilde dayattığı iki zıt davranış modelini ister istemez içselleştirmiştir. Bunlardan ilki Romantizm akımının beraberinde getirdiği yaratıcı bir sanatçı olma, kalemi ve hayal gücünün yardımıyla kendini kanıtlama idealidir. Özgürlükçü ve radikal fikirleriyle tanınan bir ailenin kızı ve İngiltere'nin en önemli şairlerinden Percy Bysshe Shelley’nin sevgilisi/eşi olarak içinde bulunduğu aile ortamlarında bu idealin baskısını hep hissetmiştir. Öte yandan dönemin muhafazakâr toplumsal koşulları ondan geleneksel kadın modeline uygun olmasını beklemektedir (Poovey 1984: 115-116). Dolayısıyla henüz genç bir kadın olan Shelley’nin, kendisini özgünlüğe, yaratıcılığa zorlayan "Romantik" anlayış ile dört duvar arasındaki evcimen kadın rolüne indirgemeye çalışan toplum şartları arasında bocalamış olması muhtemeldir.

Annesinin, babasının ve sevgilisi Percy Shelley’nin özgürlükçü fikirlerinin izinden giden Mary, birbirlerine aşık olduklarında Percy'nin evli bir adam olmasına aldırmaz ve onunla uzaklara kaçarak gayrimeşru bir ilişki yaşar. “"My Hideous Progeny”: The Lady and the Monster" adlı makalesinde Mary Shelley'nin hayatını ve Frankenstein metni üzerindeki etkisini inceleyen Mary Poovey’ye göre, annesiyle babasının kitaplarındaki özgürlükçü ve aykırı fikirleri okumak Shelley'nin toplumsal değerleri hiçe sayması için bir bahane olmuş olabilir. Ancak Shelley, annesinin William Godwin'le evliliğinden önce başka bir adamla yaşadığı yasak aşk ve evlilik dışı dünyaya getirdiği çocuk yüzünden karşılaştığı tepkiyi göz önüne alarak kendi yaşadığı ilişkinin ve aykırı davranışlarının da tepki çekeceğini tahmin etmiş olmalıdır (1984: 120). Nitekim William Godwin karısının ölümünün ardından kaleme aldığı anı kitabında (Memoirs of the Author of A Vindication of the Rights of Woman) merhum 
karısı Wollstonecraft' in aykırı ilişkilerinden açıkça söz edecek kadar özgürlükçü bir adam olsa da, Mary evli bir adam olan Percy’ye aşık olup onunla kaçtığında kızını reddeder ve uzun yıllar onunla görüşmez. William Godwin ve Mary Wollstonecraft gibi evlilik karşıtı iki yazarın çocuklarına toplumsal saygınlık kazandırmak adına evlenmiş olmaları (Mellor 1988:2) dönemin muhafazakâr toplumsal yaptırımlarının etkisini yansıtan bir diğer çarpıcı örnektir. Dolayısıyla dönemin en özgürlükçü yazarlarının bile kendilerini toplumsal koşullara ayak uydurmak zorunda hissettikleri görülmektedir.

Frankenstein, Mary Shelley'nin yasak bir ilişki yaşamayı, yani dönemin toplumsal koşullarına kıyasla daha radikal bir hayatı seçtiği gençlik yıllarında yazılmıştır. Mary Shelley, bu eserin tohumlarının Percy Shelley ve Lord Byron gibi iki önemli şairin bulunduğu, galvanizm gibi esrarengiz konular üzerine sohbetlerin yapıldığı, Almancadan Fransızcaya çevrilmiş hayalet hikâyelerinin okunduğu bir ortamda atıldığını bizzat ifade etmiştir ${ }^{3}$. Gerek o dönemki radikal yaşam tarzı, gerekse kitabın yenilikçi ve özgün temaları Shelley’nin 1818 metnini yazarken ailesinde ve sosyal çevresinde gördüğü özgürlükçü yaklaşımlara yakın bir düşünce yapısında olduğuna işaret etmektedir.

Frankenstein'ın 1818'de ilk kez basılmasından önceki yıllarda, annesinin doğumdan birkaç gün sonra hayatını kaybetmesiyle ölümle çok erken tanışan Mary, erken doğan bebeğinin ölümünün ardından kız kardeşinin intiharıyla da sarsılmıştır. 1831 yılına kadar geçen süre içerisinde ise önce peş peşe iki çocuğu daha ölür, sonra kocası Percy Shelley bir tekne kazasında hayatını kaybeder. Mary Shelley, oğlu Percy Florence ile hayatta bir başına kalır. Hayatındaki en önemli insanları birer birer kaybetmiş olmanın Mary Shelley’nin hayata bakış açısını değiştirmiş olması, onu daha içine kapanık, daha muhafazakâr ve korumacı bir kadın haline getirmiş olması mümkündür. İçinde büyüdüğü ortamda edindiği özgürlükçü fikirleri tamamen değişmediyse de en azından dış dünyaya karşı daha kapalı ve mesafeli bir tutum takınmış olması muhtemeldir.

Kısacası Mary Shelley yaşamı boyunca bir tarafta ailesindeki açık fikirli Romantik dönem yazar/şairlerin özgür ve özgün eserler yaratma teşvikinin, diğer tarafta kadınları ahlaki değerlere uygun bir biçimde yaşamaya mecbur bırakan muhafazakâr toplumsal değerlerin arasında kalmıştır. Bu ikilem Shelley'nin yazdığı kitaplarda da kendini göstermektedir: Frankenstein (1818), Mathilda (1819), Valperga (1823) ve The Last Man (1826) romanlarında annesinin özgüvenli kadın kimliğiyle Percy’nin estetik anlayışının etkileri görülürken, daha sonra yazdığı kitaplarda edebiyat kariyerini kadınlardan beklenen geleneksel davranış kalıplarına uyduğunu göstermek için kullanmıştır. Perkin Warbeck (1830), Lodore (1835), ve Falkner (1837) adlı romanlarındaki uysal, domestik kadın kahramanları aracılığıyla yansıttığı kişiliğiyle büyük ölçüde orta sınıf kadınlardan oluşan kitlesinin onayını alabilmiş ve kendi özgünlüğüne ancak “örnek” kadın imgesine bürünerek ulaşabilmiştir (Poovey 1984:116-117).

Mary Shelley'nin eserlerine yansıyan ideolojik değişim kitapların yazıldığı tarihler göz önüne alınarak değerlendirildiğinde, 1818 metninin yazıldı̆̆ı dönemlerde benimsediği özgürlükçü yaşam tarzının ve 1831 'de bu metni yeniden yazıncaya kadar geçen süre içerisinde yaşadığ 1

3 Bknz: "Introduction.” Frankenstein. Joseph M. K. (ed.) Oxford University Press: New York 2008. 
acı kayıplarla şekillenen muhafazakâr bakış açısının bu metinlere yansıdığını söylemek yanlış olmayacaktır. Dolayısıyla 1831 yılında yeniden yazılan Frankenstein'daki farklılıkları bu açıdan yorumlamak mümkündür; yani bir bakıma 1818'de toplumun geneline kıyasla radikal bir imaj çizen Shelley’nin 1831 metniyle bu imajı da yeniden yazmaya çalıştığı söylenebilir.

\section{Frankenstein 1818 Metninin 1831'de Yeniden Yazımı ${ }^{4}$}

André Lefevere, Anne Frank'in günlüklerinin yeniden yazımı üzerine yaptığı incelemede metnin iki versiyonunu (ilk metni ve yeniden yazılmış metni) karşılaştırmış ve iki metin arasındaki dilsel, metinsel ve söylemsel farklılıkları (yeniden) yazarın tercihleri olarak değerlendirip yazarın imgesinin nasıl "yeniden” kurgulandığını ortaya koymuştur (1992:5972). Lefevere'in yöntemi ışı̆̆ında bu çalışmamızda Mary Shelley'nin Frankenstein'1 1831'de yeniden yazarken yaptığı değişiklikleri ve eklemeleri, bu yeniden yazımın olası ideolojik sebeplerini de göz önünde bulundurarak metinlerde farklılık gösteren belirli temalar bağlamında gruplandırdık. Shelley’nin kendi metnini yeniden yazdığını gösteren örnekleri yorumlamaya çalıştık. Bu noktada bütüncemizdeki metinsel ve söylemsel verilerden yola çıkarak yeniden yazımın ardındaki bireysel ve toplumsal ideolojiyi betimleyen bir inceleme gerçekleştirdik.

\subsection{Yeniden Yazlan Aile İmgesi}

Mary Shelley’nin yaşam öyküsünde 1818 ve 1831 yılları arasında aile değerleri açısından görülen değişimin, yani anne ve babasının özgürlükçü anlayışını benimseyerek büyümüş Shelley’nin yaşadığı kayıplarla yıllar içerisinde daha muhafazakâr bir kadına dönüşmesinin, yeniden yazılmış metne de yansıdı̆̆ı görülmektedir.

\begin{tabular}{|c|c|}
\hline \multicolumn{2}{|l|}{ Örnek $1^{5}$} \\
\hline 1818 (syf. 20) & 1831 (syf. 33) \\
\hline $\begin{array}{l}\text { When my father became } \\
\text { a husband and a parent, } \\
\text { he found his time so } \\
\text { occupied by the duties } \\
\text { of his new situation, that } \\
\text { he relinquished many of } \\
\text { his public employments, } \\
\text { and devoted himself } \\
\text { to the education of his } \\
\text { children. }\end{array}$ & $\begin{array}{l}\text { There was a considerable difference between the ages of my parents, but this } \\
\text { circumstance seemed to unite them only closer in bonds of devoted affection. } \\
\text { (...) There was a show of gratitude and worship in his attachment to my } \\
\text { mother, differing wholly from the doating fondness of age, for it was inspired } \\
\text { by reverence for her virtues, and a desire to be the means of, in some degree, } \\
\text { recompensing her for the sorrows she had endured, but which gave inexpressible } \\
\text { grace to his behaviour to her. Everything was made to yield to her wishes and her } \\
\text { convenience. He strove to shelter her, as a fair exotic is sheltered by the gardener, } \\
\text { from every rougher wind, and to surround her with all that could tend to excite } \\
\text { pleasurable emotion in her soft and benevolent mind. }\end{array}$ \\
\hline
\end{tabular}

4 Bu çalışmada Oxford World’s Classics dizisinden çıkan 1818 ve 1831 metinleri kullanılmıştır: Shelley, Mary. Frankenstein 1818 Text. Nick Groom (ed.) Oxford University Press: New York 2019. Shelley, Mary. Frankenstein. Joseph M. K. (ed.) Oxford University Press: New York 2008.

5 Tablolardaki "1818” ve "1831" rakamları 1818 ve 1831 yıllarında yazılmış metinlere referans vermektedir. 
Örnekteki 1818 ve 1831 metinleri karşılaştırmalı okunduğunda, Shelley’nin 1831 metninde Victor Frankenstein'ın annesiyle babası üzerinden eşler arasındaki sevgi bağını güçlendirdiği görülmektedir. 1818 metninde "[He] devoted himself to the education of his children" cümlesinde babasının evlenip çocuk sahibi olduktan sonra kendisini çocuklarının eğitimine "adadığı" ifade edilse de eşler arasındaki ilişkiye değinilmemiştir. 1831 metninde ise babasının annesine duyduğu yoğun hisleri ifade eden "devoted affection" (düşkünlük), "gratitude" (minnettarlık), "worship" (tapınma), "attachment" (bağlılık), "He strove to shelter her" (Onu koruyup kollamaya uğraştı) gibi sözcük ve cümleler dikkat çekmektedir. 1831 metnindeki ifadeler Frankenstein'ın babasının eşine adeta "taptığııı", onu "her türlü zorluktan korumaya" çabaladığını vurgulamaktadır. Shelley, 1831 metninde Frankenstein'ın annesiyle babası arasındaki sevgi bağının ne kadar güçlü olduğunu sözcük seçimleriyle vurgulayarak onun birbirine son derece düşkün ebeveynlerin çocuğu olarak mutlu bir aile ortamında yetiştiğini göstermektedir.

\begin{tabular}{|l|l|}
\hline \multicolumn{2}{|l|}{ Örnek 2 } \\
\hline $\mathbf{1 8 1 8}$ (syf. 20) & $\mathbf{1 8 3 1}$ (syf. 34) \\
\hline $\begin{array}{l}\text { No creature could } \\
\text { have more tender } \\
\text { parents than mine. } \\
\text { My improvement } \\
\text { and health were } \\
\text { their constant care, } \\
\text { especially as I } \\
\text { remained for several } \\
\text { years their only } \\
\text { child. }\end{array}$ & $\begin{array}{l}\text { I remained for several years their only child. Much as they were attached to each } \\
\text { other, they seemed to draw inexhaustible stores of affection from a very mine of } \\
\text { love to bestow them upon me. My mother's tender caresses, and my father's smile } \\
\text { of benevolent pleasure while regarding me, are my first recollections. I was their } \\
\text { plaything and their idol, and something better - their child, the innocent and helpless } \\
\text { creature bestowed on them by Heaven, whom to bring up to good, and whose future } \\
\text { lot it was in their hands to direct to happiness or misery, according as they fulfilled their } \\
\text { duties towards me. With this deep consciousness of what they owed towards the being } \\
\text { to which they had given life, added to the active spirit of tenderness that animated } \\
\text { both, it may be imagined that while during every hour of my infant life I received a } \\
\text { lesson of patience, of charity, and of self-control, I was so guided by a silken cord that } \\
\text { all seemed but one train of enjoyment to me. }\end{array}$ \\
\hline
\end{tabular}

Birinci örnekteki yeniden yazımda eşler arasındaki sevgi bağının ne kadar güçlü olduğu vurgulanırken, ikinci örnekte ebeveynlerin çocukları Frankenstein'a duydukları sevginin vurgulandığı görülmektedir. Shelley, 1818 metnindeki "No creature could have more tender parents than mine" ifadesiyle ebeveynlerin ne kadar şefkatli ve sevecen olduğuna değinmiş ve Frankenstein'ın sağlığına ve gelişimine özen gösterdiklerini belirtmiştir. 1831 metninde ise "inexhaustible stores of affection" (bitmek tükenmek bilmez sevgi kaynakları), "tender caresses" (şefkatli okşayışlar) gibi ifadelerle birbirlerine oldukça düşkün olan ebeveynlerin Frankenstein'a da büyük bir sevgi duyduklarının altı çizilmektedir. "I was ... their idol" (onların idolleriydim), "the innocent and helpless creature bestowed on them by Heaven" (cennetten bahşedilmiş masum ve aciz bir mahluk) gibi abartılı ifadeler çiftin oğullarına olan sevgi ve ilgisinin ne denli büyük olduğunu göstermektedir. Birinci ve ikinci örneklerdeki yeniden yazılmış metinler birlikte değerlendirildiğinde Shelley'nin yeniden yazımla aile bağlarını, dolayısıyla da aile kavramını yüceltmeye çalıştı̆̆ını söyleyebiliriz. 
1831 yılına kadar çocuklarını ve eşi Percy’yi kaybetmiş olan Shelley oğluyla birlikte hayatta bir başına kalmıştı, bu nedenle karı-koca, ebeveyn-çocuk ilişkisinin bu denli sevgi dolu bir şekilde vurgulamış olması Shelley’nin eski mutlu günlerine duyduğu özleme bağlanabilir. Öte yandan 1831 metnindeki farklılıklar poetik açıdan değerlendirildiğinde, fazlasıyla mutlu aile tablosunun Frankenstein'ın daha sonra yaşayacağı trajedileri çok daha çarpıcı hâle getirdiği anlaşılmaktadır; yani Shelley'nin aile kurumunu ve bu sevgi dolu ortamı bu denli vurgulamasının altında yatan neden, romanda daha sonra yaşanacak korkunç olayların etkisini artırmak da olabilir. Anne ve babasından büyük bir sevgi ve ilgi gören Victor Frankenstein'ın kendi yarattığı canavara sevgi ve ilgi duymaması, aksine ondan tiksinip uzaklaşması ise yeniden yazılmış metinde altı çizilen bir diğer çarpıcı tezatı oluşturmaktadır.

\begin{tabular}{|c|c|}
\hline \multicolumn{2}{|l|}{ Örnek 3} \\
\hline 1818 (syf. 20) & 1831 (syf. 34-35) \\
\hline $\begin{array}{l}\text { My father had a sister, whom he tenderly loved, and } \\
\text { who had married early in life an Italian gentleman. } \\
\text { (...) About the time I mentioned she died; and a } \\
\text { few months afterwards he received a letter from } \\
\text { her husband, acquainting him with his intention } \\
\text { of marrying an Italian lady, and requesting my } \\
\text { father to take charge of the infant Elizabeth, the } \\
\text { only child of his deceased sister. "It is my wish," } \\
\text { he said, "that you should consider her as your } \\
\text { own daughter, and educate her thus. Her mother's } \\
\text { fortune is secured to her, the documents of which } \\
\text { I will commit to your keeping. Reflect upon this } \\
\text { proposition; and decide whether you would prefer } \\
\text { educating your niece yourself to her being brought up } \\
\text { by a stepmother." }\end{array}$ & $\begin{array}{l}\text { Their benevolent disposition often made them enter } \\
\text { the cottages of the poor. (...) She found a peasant } \\
\text { and his wife, hard working, bent down by care and } \\
\text { labour, distributing a scanty meal to five hungry } \\
\text { babes. Among these there was one which attracted } \\
\text { my mother far above all the rest. (...) [My mother } \\
\text { and father] were fond of the sweet orphan. Her } \\
\text { presence had seemed a blessing to them; but it would } \\
\text { be unfair to her to keep her in poverty and want, when } \\
\text { Providence afforded her such powerful protection. } \\
\text { They consulted their village priest, and the result } \\
\text { was that Elizabeth Lavenza became the inmate } \\
\text { of my parents' house - my more than sister-the } \\
\text { beautiful and adored companion of all my occupations } \\
\text { and my pleasures. }\end{array}$ \\
\hline
\end{tabular}

Bu örnekte 1818 ve 1831 metinlerinde Elizabeth'in Frankenstein ailesine girişinin farklı hikâyeleri yer almaktadır. Elizabeth, 1818 metninde Alphonse Frankenstein'ın kız kardeşinin kızı, yani Victor Frankenstein'ın öz kuzenidir. Alphonse “onu kendi kızı gibi” görüp büyütecektir. Frankenstein ailesine emanet edilen yalnızca Elizabeth değildir; annesinden ona kalan servet de yine dayısı Alphonse'a emanet edilmiştir. 1831 metninde ise Elizabeth, Frankenstein ailesinin evlatlığıdır. Elizabeth'in evlat ediniliş anlatısının yanı sıra metinde doğrudan geçen "orphan" (yetim) sözcüğü de bu durumu vurgulamaktadır. 1831 metninde aile imgesinin yeniden yazıldığını gösteren bir diğer önemli unsur Elizabeth'in Frankenstein ailesiyle akrabalık bağının ortadan kalkmış olmasıdır. 


\begin{tabular}{|l|l|}
\hline \multicolumn{2}{|l|}{ Örnek 4} \\
\hline $\mathbf{1 8 1 8}$ (syf. 26) & $\mathbf{1 8 3 1}$ (syf. 43) \\
\hline $\begin{array}{l}\text { Elizabeth, my love, you must supply my place to your } \\
\text { younger cousins. }\end{array}$ & $\begin{array}{l}\text { Elizabeth, my love, you must supply my place to my } \\
\text { younger children. }\end{array}$ \\
\hline \hline $\mathbf{1 8 1 8}$ (syf. 65) & $\mathbf{1 8 3 1}$ (syf. 93) \\
\hline $\begin{array}{l}\text { Elizabeth read my anguish in my countenance, and } \\
\text { kindly taking my hand said, "My dearest cousin, you } \\
\text { must calm yourself." }\end{array}$ & $\begin{array}{l}\text { Elizabeth read my anguish in my countenance, and } \\
\text { kindly taking my hand, said, "My dearest friend, you } \\
\text { must calm yourself." }\end{array}$ \\
\hline \hline $\mathbf{1 8 1 8}$ (syf. 114) & $\mathbf{1 8 3 1}$ (syf. 151) \\
\hline $\begin{array}{l}\text { Alas! to me the idea of an immediate union with } \mathbf{m y} \\
\text { cousin was one of horror and dismay. }\end{array}$ & $\begin{array}{l}\text { Alas! to me the idea of an immediate union with my } \\
\text { Elizabeth was one of horror and dismay. }\end{array}$ \\
\hline
\end{tabular}

Victor ve Elizabeth hem 1818 hem de 1831 metinlerinde birbirlerine "kuzen" diye seslenirler. Fakat bir önceki örnekte değinildiği gibi, Victor ve Elizabeth 1818 metninde öz kuzenlerdir; 1831 metninde ise böyle bir akrabalık söz konusu değildir. Metnin farklı yerlerinden alınan bu örnekler 1818 metnindeki kimi “cousin” (kuzen) sözcüklerinin 1831 metninde "friend” (arkadaş) ya da “Elizabeth” gibi sözcüklerle değiştirildiğini göstermektedir. Sözcük seçimleriyle de vurgulanan farklılığın sebebi, Elizabeth ve Victor'un aralarında gerçek bir kan bağı bulunmadığının altını çizmek, okura bu gerçeği tekrar göstermek olabilir. Nitekim 1818 metninde Elizabeth ve Victor arasında kan bağı olması aralarındaki evlilik ilişkisine ensest boyutu katmaktadır. Metnin yazıldığ Victor ve Elizabeth arasındaki kan bağının 1831 metninde ortadan kaldırılması Shelley'nin bu dönemde daha muhafazakâr bir bakış açısına sahip olduğunu ya da ensest imasının neden olabileceği ahlaki eleştirileri bertaraf etmek istediği şeklinde yorumlanabilir. Dolayısıyla 1831 metninde yeniden yazılan Elizabeth-Victor ilişkisi Shelley'nin ideolojisinde dikkat çekici bir değişikliğe işaret etmektedir.

1818 ve 1831 metinleri bu altı örnek üzerinden ele alındığında aile imgesi açısından çarpıcı bir farklılık görülmektedir. Shelley 1818 metninde herhangi bir özelliğini vurgulamadığı sıradan bir aile çerçevesi çizmiştir. 1818'deki aile imgesinin dikkat çekici tek yanı Frankenstein ailesinin yeğenleri Elizabeth'in bakımını üstlenmesidir, çünkü Elizabeth ileride (roman serüveninde, devamında?) kuzeni Victor ile evlenecektir. 1831 metnine bakıldığında ise Shelley’nin güçlü duyguları ifade eden sözcük seçimleriyle aile imgesini çok daha güçlü ve sevgi dolu bir hale getirdiği görülmektedir. Elizabeth'in aileyle olan kan bağının ortadan kaldırması ise Shelley'nin toplumsal normlara daha uygun bir ilişki modeli çizdiğini göstermektedir.

\subsection{Yeniden Yazlan Kadın İmgesi}

Mary Shelley’nin özgürlükçü anlayıştan muhafazakâr tutuma doğru yaşadığı değişim kadın imgesinin yeniden yazımında da görülmektedir. 


\begin{tabular}{|l|l|}
\hline \multicolumn{2}{|l|}{ Örnek 5 } \\
\hline $\mathbf{1 8 1 8}$ (syf. 21) & $\mathbf{1 8 3 1}$ (syf. 34) \\
\hline $\begin{array}{l}\text { I have often heard my mother say, } \\
\text { that she was at that time the most } \\
\text { beautiful child she had ever seen, and } \\
\text { shewed signs even then of a gentle and } \\
\text { affectionate disposition. }\end{array}$ & $\begin{array}{l}\text { Their benevolent disposition often made them enter the cottages } \\
\text { of the poor. This, to my mother, was more than a duty; it was a } \\
\text { necessity, a passion-remembering what she had suffered, and how } \\
\text { she had been relieved-for her to act in her turn the guardian } \\
\text { angel to the afflicted. }\end{array}$ \\
\hline
\end{tabular}

1831 metninde romanın önemli iki karakteri Elizabeth ve Caroline'ın kadın imgelerinde çarpıcı farklılıklar gözlemlenmektedir. Caroline 1818 metninde Elizabeth'ten bahsederken, "the most beautiful child she had ever seen" (gördüğü en güzel çocuk) ifadesini kullanır. Caroline kocasının yetim kalmış yeğenine kucak açan bir eş ve onu çok seven bir anne olarak betimlenir. 1831 metninde ise ona çok daha üstün bir kadın imgesi biçilmiştir. Caroline için yardıma muhtaç olanlara yardım etmek "bir görevden de öte", bir "gereklilik", bir "tutku"dur. Shelley 1831 metninde kullandığı "the guardian angel” ifadesiyle ailesiyle hiçbir akrabalık bağı bulunmayan zavallı yetim Elizabeth'i evlat edinen ve onu bir anne şefkatiyle seven Caroline'1 bir “iyilik meleği””ne dönüştürmüştür. Öyle ki, Caroline hastalanan Elizabeth'i görmek, onunla ilgilenmek uğruna hastalık kapıp ölmeyi bile göze alır:

\begin{tabular}{|l|l|}
\hline \multicolumn{2}{|l|}{ Örnek 6 } \\
\hline $\mathbf{1 8 1 8}$ (syf. 26) & $\mathbf{1 8 3 1}$ (syf. 42) \\
\hline $\begin{array}{l}\text { Elizabeth had caught the scarlet fever; but } \\
\text { her illness was not severe, and she quickly } \\
\text { recovered. During her confinement, many } \\
\text { arguments had been urged to persuade my } \\
\text { mother to refrain from attending upon her. She } \\
\text { had, at first, yielded to our entreaties; but when } \\
\text { she heard that her favourite was recovering, } \\
\text { she could no longer debar herself from her } \\
\text { society, and entered her chamber long before } \\
\text { the danger of infection was past. }\end{array}$ & $\begin{array}{l}\text { Elizabeth had caught the scarlet fever; her illness was severe, } \\
\text { and she was in the greatest danger. During her illness, many } \\
\text { arguments had been urged to persuade my mother to refrain } \\
\text { from attending upon her. She had, at first, yielded to our } \\
\text { entreaties; but when she heard that the life of her favourite } \\
\text { was menaced, she could no longer control her anxiety. She } \\
\text { attended her sick bed-her watchful attentions triumphed } \\
\text { over the malignity of the distemper-Elizabeth was saved, } \\
\text { but the consequences of this imprudence were fatal to her } \\
\text { preserver. }\end{array}$ \\
\hline
\end{tabular}

1818 metnindeki anlatıda Caroline çok sevdiği Elizabeth'in odasına kızın iyileştiğini zannettiği için girer, ancak Elizabeth henüz iyileşmediği için Caroline enfeksiyon kapar ve ölür. 1831 metninde ise Caroline, kızın ağır bir hastalık geçirdiğini bilmesine rağmen, hayatının tehlikede olduğunu düşündüğü evlatlık kızı için çok endişelendiğinden "daha fazla dayanamaz" ve bir bakıma ölümü göze alarak kızın odasına girer; sonuçta Elizabeth iyileşir ancak Caroline ölür. Bu örnek de evlatlık kızı için ölümü göze alıp can veren Caroline'a biçilen fedakâr, "iyilik meleği anne” imgesini vurgulamaktadır. Dolayısıyla, 1818 metnindeki sıradan kadın imgesi, 1831 metninde idealleştirilmiş, kutsallaştırılmış bir kadın imgesine dönüştürülerek yeniden yazılmıştır. 


\begin{tabular}{|l|l|}
\hline \multicolumn{2}{|l|}{ Örnek 7 } \\
\hline $\mathbf{1 8 1 8}$ (syf. 21) & $\mathbf{1 8 3 1}$ (syf. 35-36) \\
\hline $\begin{array}{l}\text { I have often heard my mother say, that } \\
\text { she was at that time the most beautiful } \\
\text { child she had ever seen, and shewed signs } \\
\text { even then of a gentle and affectionate } \\
\text { disposition. These indications, and a } \\
\text { desire to bind as closely as possible the } \\
\text { ties of domestic love, determined my } \\
\text { mother to consider Elizabeth as my } \\
\text { future wife; a design which she never } \\
\text { found reason to repent. }\end{array}$ & $\begin{array}{l}\text { Onther had said playfully-"I have a pretty present for my } \\
\text { Sictor-to-morrow he shall have it." And when, on the morrow, } \\
\text { childish seriousness, interpreted her words literally, and looked upon } \\
\text { Elizabeth as mine-mine to protect, love, and cherish. All praises } \\
\text { bestowed on her, I received as made to a possession of my own. } \\
\text { We called each other familiarly by the name of cousin. No word, no } \\
\text { expression could body forth the kind of relation in which she stood to } \\
\text { me-my more than sister, since till death she was to be mine only. }\end{array}$ \\
\hline
\end{tabular}

1831 metninde Elizabeth karakterinde de çarpıcı bir farklılık görülmektedir. 1818 metninde, Caroline gördüğü en güzel çocuk olan çok sevdiği Elizabeth'in gelecekte oğlu Victor'un karısı olacağını düşünmektedir. "A desire to bind as closely as possible the ties of domestic love" (aile içi sevgi bağlarını mümkün olduğunca sıkı tutma isteği) ifadesi bu düşüncenin bir annenin yüreğinden geçen iyi niyetli bir dilek olduğunu göstermektedir. Fakat 1831 metninde tekrarlanan "present" ve "gift" gibi sözcüklerle vurgulandığı üzere, Elizabeth annesinin Victor'a "sunduğu," "ölünceye kadar yalnızca ona ait olacak" "güzel bir hediye"dir. Victor onu "ömür boyu koruyup kollayacağı", kendisinin ilgi ve sevgisine muhtaç bir varlık olarak görmektedir. Böylece Elizabeth karakteri 1831 metninde bir hediye gibi sunulan, korunup kollanmaya muhtaç, edilgen bir kadın olarak yeniden yazılmıştır.

\begin{tabular}{|l|l|}
\hline \multicolumn{2}{|l|}{ Örnek 8 } \\
\hline $\mathbf{1 8 1 8}$ (syf. 116) & $\mathbf{1 8 3 1}$ (syf. 153-154) \\
\hline $\begin{array}{l}\text { Elizabeth approved of the reasons of } \\
\text { my departure, and only regretted that } \\
\text { she had not the same opportunities } \\
\text { of enlarging her experience, and } \\
\text { cultivating her understanding. She } \\
\text { wept, however, as she bade me farewell, } \\
\text { and entreated me to return happy and } \\
\text { tranquil. }\end{array}$ & $\begin{array}{l}\text { My journey had been my own suggestion, and Elizabeth, } \\
\text { therefore, acquiesced: but she was filled with disquiet at the idea } \\
\text { of my suffering, away from her, the inroads of misery and grief. It } \\
\text { had been her care which provided me a companion in Clerval- } \\
\text { and yet a man is blind to a thousand minute circumstances, which } \\
\text { call forth a woman's sedulous attention. She longed to bid me } \\
\text { hasten my return,-a thousand conflicting emotions rendered } \\
\text { her mute as she bade me a tearful silent farewell. }\end{array}$ \\
\hline
\end{tabular}

$\mathrm{Bu}$ örnek de Elizabeth bağlamında 1831 metninde yeniden yazılan kadın imgesini göstermektedir. 1818 metnindeki “approved” (onayliyordu) ifadesinden Victor'un İngiltere'ye gitme kararında Elizabeth'e de söz hakkı tanındığı anlaşılmaktadır; aynı zamanda Elizabeth'in "tecrübe ve bilgi birikimini artırma firsatı"nın kendisine tanınmamasından "yakınması" onun bir kadın olarak bu haksız durumu sorguladığını gösterir. Öte yandan 1831 metnindeki " $M y$ journey had been my own suggestion" (Bu seyahat benim fikrimdi) cümlesi İngiltere'ye gitme kararının tamamen Victor'a ait olduğunu, “acquiesced" sözcüğü ise Elizabeth'in bu karara 
"razı olduğunu” göstermektedir; yani Elizabeth'e bu konuda söz hakkı tanınmamıştır. 1831 metnindeki Elizabeth, 1818 metnindekinin aksine, kendi konumunu ve kendisine sunulmayan firsatları sorgulamaz; öyle ki nişanlısı Victor'a çabuk dönmesini istediğini dahi söyleyemez, "sessiz bir vedayla" yetinir. 1831 metninde edilgen bir konuma indirgenen Elizabeth'in de tıpkı Caroline karakteri gibi, başlıca görevi kocasına itaat etmek ve çocuklarını büyütmek olan ideal kadın, "Evdeki Melek" modeline, yani dönemin toplumsal cinsiyet rollerinin belirlediği kadın imgesine uygun düşecek biçimde yeniden yazıldığı görülmektedir.

1818 metninde her kadın gibi bakımını üstlendiği çocuklara sevgi ve ilgi gösteren, fikir danışılan, kendisine tanın(may)an şartları sorgulayan bir kadın imgesi çizilmiştir; 1831 metninde ise "iyilik meleği" ifadesiyle adeta kutsal bir konuma taşınan, söz hakkı tanınmayan, fikrini beyan etmekten bile çekinen ve kendisine sunulanı sorgusuz sualsiz kabul eden bir kadın imgesi vardır. Kadın imgesinin bu şekilde yeniden yazılmış olması Shelley’nin metne yansıyan ideolojisinde çarpıcı bir farklılık olduğuna işaret etmektedir. Daha önce yaşam öyküsü bağlamında değindiğimiz ideolojik ikilemin (özgürlükçü/muhafazakâr) 1831 metninde, özellikle kadın imgesinin yeniden yazımında, kadını ikincil konuma indirgeyen muhafazakâr toplumsal değerlerden yana ağır bastığı anlaşılmaktadır.

\subsection{Yeniden Yazlan Erkek Imgesi}

Mary Shelley, 1818 ve 1831 metinlerinde, 19. yüzyılın ilk yarısında ekonomik güce sahip, büyük hırslar peşine düşen erkek tipinin yanı sıra, olgun, yaptıkları sorgulayan, ağırbaşı bir erkek tipi de yaratarak dönemin farklı erkek imgelerini ortaya koymaktadır.

\begin{tabular}{|l|l|}
\hline \multicolumn{2}{|l|}{ Örnek 9 } \\
\hline $\mathbf{1 8 1 8}$ (syf. 163) & $\mathbf{1 8 3 1}$ (syf. 212) \\
\hline $\begin{array}{l}\text { There is something terribly appalling in our } \\
\text { situation, yet my courage and hopes do not desert } \\
\text { me. We may survive; and if we do not, I will } \\
\text { repeat the lessons of my Seneca, and die with } \\
\text { a good heart. }\end{array}$ & $\begin{array}{l}\text { There is something terribly appalling in our situation, yet } \\
\text { my courage and hopes do not desert me. Yet it is terrible } \\
\text { to reflect that the lives of all these men are endangered } \\
\text { through me. If we are lost, my mad schemes are the } \\
\text { cause. }\end{array}$ \\
\hline
\end{tabular}

Frankenstein metninin çerçeve anlatısını oluşturan mektupları yazan ve Victor Frankenstein'ı ölmek üzereyken bulan kutup kâşifi Kaptan Robert Walton tıpkı Frankenstein’ın gençliği gibi hırslı, amacından sapmayan bir adamdır. Fakat 1831 metninde Walton karakteri de yeniden yazılmıştır. Bu örnekteki iki metinde de Walton'ın gemisi ve içindeki gemiciler ölüm tehlikesiyle karşı karşıyadır. 1818 metninde Victor'un hikâyesini ve uyarılarını işiten Walton, bu uyarılara ve söz konusu ölüm tehlikesine rağmen gemideki adamları isyan edinceye kadar keşif yolundan geri dönmeyi düşünmez; sonunda ölüm de olsa yolunda devam etmeye kararlıdır. 1831 metninde ise "it is terrible to reflect that the lives of all these men are endangered through me"

6 Bknz: Patmore, Coventry (1863) The Angel in the House Part I \& II. London: Macmillan \& Co. 
sözleriyle gemideki adamların hayatını tehlikeye attığını itiraf eder; "If we are lost, my mad schemes are the cause" cümlesiyle, buzulların arasında kaybolup öldükleri takdirde bu trajik sonun sorumlusunun kendi "çılgın planları" olduğunu kabul eder. 1818 metninde hirsından gözü kör olan, başkalarını düşünmeyen Walton, 1831'de eylemlerini ve kararlarını sorgulayan ve Frankenstein'ın yaşadıklarından ders alan bir adam haline gelmiştir. Bu açıdan, 1818 metnindeki gözünü başarı hırsı bürümüş erkek imgesi, 1831 metninde eylemlerini sorgulayan, sorumluluklarını kabul eden daha olgun ve aydın bir erkek imgesiyle yeniden yazılmıştır.

\begin{tabular}{|l|l|}
\hline \multicolumn{2}{|l|}{ Örnek 10 } \\
\hline $\mathbf{1 8 1 8}$ (syf. 27) & $\mathbf{1 8 3 1}$ (syf. 44) \\
\hline $\begin{array}{l}\text { He bitterly lamented that he was unable to accompany } \\
\text { me: but his father could not be persuaded to part with } \\
\text { him, intending that he should become a partner with }\end{array}$ & $\begin{array}{l}\text { He had endeavoured to persuade his father to permit } \\
\text { him to accompany me, and to become my fellow } \\
\text { student; but in vain. His father was a narrow- }\end{array}$ \\
$\begin{array}{l}\text { theory, that learning was superfluous in the commerce } \\
\text { of ordinary life. Henry had a refined mind; he had no } \\
\text { desire to be idle, and was well pleased to become his } \\
\text { father's partner, but he believed that a man might } \\
\text { be a very good trader, and yet possess a cultivated } \\
\text { understanding. }\end{array}$ & $\begin{array}{l}\text { aspirations and ambition of his son. Henry deeply } \\
\text { felt the misfortune of being debarred from a liberal } \\
\text { education. He said little; but when he spoke, I read } \\
\text { in his kindling eye and in his animated glance a } \\
\text { restrained but firm resolve not to be chained to the } \\
\text { miserable details of commerce. }\end{array}$ \\
\hline
\end{tabular}

Çizdiği profilde çarpıcı bir değişim görülen bir diğer karakter ise Victor'un yakın dostu Henry Clerval'dır. 1818 metnindeki "pleased to become his father's partner" ifadesi, iyi bir eğitim almak isteyen, ancak babasını bunun için ikna edemeyen Clerval'ın, babasının çizdiği geleceğe "razı olduğunu” göstermektedir. Clerval 1831 metninde de babasının sözünden çıkmaz, fakat "I read in his kindling eye and in his animated glance a restrained but firm resolve" cümlesinden anlaşıldığı üzere, içinde yanıp tutuşan hırslı karakteri "çakmak çakmak gözlerinde" ve "capcanlı bakışlarında" kendini belli etmektedir. Clerval, sıkıcı ticaret hayatına "zincirli" kalmamaya kararlıdır.

\begin{tabular}{|l|l|}
\hline \multicolumn{2}{|l|}{ Örnek 11 } \\
\hline $\mathbf{1 8 1 8}$ (syf. 119-120) & $\mathbf{1 8 3 1}$ (syf. 158) \\
\hline $\begin{array}{l}\text { But in Clerval I saw the image of } \\
\text { my former self; he was inquisitive, } \\
\text { and anxious to gain experience } \\
\text { and instruction. The difference of } \\
\text { manners which he observed was } \\
\text { to him an inexhaustible source of } \\
\text { instruction and amusement. He } \\
\text { was for ever busy; and the only } \\
\text { check to his enjoyments was my } \\
\text { sorrowful and dejected mien. }\end{array}$ & $\begin{array}{l}\text { But in Clerval I saw the image of my former self; he was inquisitive, and } \\
\text { anxious to gain experience and instruction. The difference of manners } \\
\text { which he observed was to him an inexhaustible source of instruction } \\
\text { and amusement. He was also pursuing an object he had long had in } \\
\text { view. His design was to visit India, in the belief that he had in his } \\
\text { knowledge of its various languages, and in the views he had taken of } \\
\text { its society, the means of materially assisting the progress of European } \\
\text { colonisation and trade. In Britain only could he further the execution } \\
\text { of his plan. He was for ever busy; and the only check to his enjoyments } \\
\text { was my sorrowful and dejected mind. }\end{array}$ \\
\hline
\end{tabular}


1831 metnine eklenen vurgulanmış kısımda Clerval'ın yıllar öncesinden kendini belli eden hırsının somutlaşmış hâli görülmektedir. 1831 metnindeki Clerval sömürgeleştirme hareketinin bir parçası olarak Hindistan'a gitmeyi amaçlamaktadır. "He was also pursuing an object he had long had in view" cümlesinden onun bu sömürgeleştirici amac1 "uzun zamandır tasarladı ğ $ı$ " anlaşılmaktadır. Clerval'ın her iki metinde de doğu dillerine ilgi duyması bu bakış açısıyla yeniden gözden geçirildiğinde, bu durum 1818 metninde masum bir ilgi alanı olarak görülürken, 1831 metninde Clerval'ın sömürgeci planlarının aracı hâline gelmiştir. Dolayısıyla Clerval'ın kişiliği 1831 metninde çarpıcı bir biçimde yeniden yazılmıştır. Walton'ın aksine Clerval karakterinde, 1818 metninde birtakım entelektüel ilgi alanları olan, ancak kendisi için çizilen sınırların dışına çıkmayan uysal erkek imgesi, sömürgeci amaçlar güden hırslı erkek imgesine dönüşmüştür.

Erkek imgesi Walton ve Clerval karakterlerinde farklı biçimlerde yeniden yazılmış gibi görünse de her ikisinin de dönemin erkek imgesinin iki farklı yüzünü yansıttıkları görülmektedir. Bu imgenin bir tarafında kendisine eğitim ve kariyer gibi fırsatlar sunulan modern ve aydın bir erkek temsili görülürken, diğer tarafında bu modern ve aydın erkek emperyalist hırslar peşindedir. Ancak hem Walton'ın kuzey kutbunu keşfetme amacı, hem de Clerval'ın sömürgecilik planları başarısızlıkla sonuçlanır. Shelley'nin erkek imgesini bu iki karakter üzerinden yeniden yazması erkeklerle kadınlar arasındaki firsat eşitsizliğine de dikkat çekmektedir. Walton ve Clerval karakterlerinin gelişimini ve sonlarını daha derin bir okumayla ele alırsak, kadın imgesini açıkça muhafazakâr bir yaklaşımla yeniden yazan Shelley’nin aslında toplumun dayattığı erkek imgesine de örtük ama çarpıcı bir eleştiri getirdiğini söyleyebiliriz. Yeniden yazılan Robert Walton, Henry Clerval ve hatta Victor Frankenstein kendilerine eğitim ve kariyer gibi olanaklar sunulmuş, büyük idealleri olan erkeklerdir. Walton kutupları keşfetmek için yola koyulur, Clerval sömürgeci planların bir parçası olmayı tasarlar, Frankenstein ise tanrı rolüne soyunup bir canavar yaratır. Fakat hırslı egoları kontrolden çıkan üç erkeğin idealleri büyük birer başarısızlıkla sonuçlanır. Walton kutupları keşfedemeden ülkesine geri dönmek zorunda kalır, Clerval Hindistan'a doğru yola çıkamadan canavarın elinde hayatını kaybeder, Frankenstein ise kendi yaratısının gazabına uğrar. Mary Shelley'nin 1831'de yeniden yazdığı metni bu bakış açısıyla okuduğumuzda Shelley'nin toplum tarafindan önüne her türlü firsat sunulan ancak "erkek" egoları kontrolden çıkıp kendi yıkımını yaratan erkek imgesine de derin bir eleştiri getirdiğini söyleyebiliriz.

\subsection{Yeniden Yazılan $\ddot{O}_{z g u ̈ r}$ İrade}

Mary Shelley 1818 metnini henüz çok gençken, özgür iradeyle hayatını şekillendirebileceği anlayışıyla kaleme almıştır, ancak 1831 metnine kadar geçen süreçte yaşamış olduğu trajik olayların etkisiyle hayata bakış açısının değiştiği görülmektedir. 


\begin{tabular}{|c|c|}
\hline \multicolumn{2}{|l|}{ Örnek 12} \\
\hline 1818 (syf. 25) & 1831 (syf. 41-42) \\
\hline $\begin{array}{l}\text { The lecture, being therefore one of the } \\
\text { last, was entirely incomprehensible to } \\
\text { me. The professor discoursed with the } \\
\text { greatest fluency of potassium and boron, } \\
\text { of sulphates and oxyds, terms to which } \\
\text { I could affix no idea; and I became } \\
\text { disgusted with the science of natural } \\
\text { philosophy, although I still read Pliny } \\
\text { and Buffon with delight, authors, in my } \\
\text { estimation, of nearly equal interest and } \\
\text { utility. }\end{array}$ & $\begin{array}{l}\text { By one of those caprices of the mind, which we are perhaps most } \\
\text { subject to in early youth, I at once gave up my former occupations; } \\
\text { set down natural history and all its progeny as a deformed and } \\
\text { abortive creation; and entertained the greatest disdain for a would-be } \\
\text { science, which could never even step within the threshold of real } \\
\text { knowledge. (...) When I look back, it seems to me as if this almost } \\
\text { miraculous change of inclination and will was the immediate } \\
\text { suggestion of the guardian angel of my life- the last effort made } \\
\text { by the spirit of preservation to avert the storm that was even then } \\
\text { hanging in the stars, and ready to envelope me. (...) Destiny was } \\
\text { too potent, and her immutable laws had decreed my utter and } \\
\text { terrible destruction. }\end{array}$ \\
\hline
\end{tabular}

1818 ve 1831 metinleri arasındaki en çarpıcı farklardan biri özgür iradenin yeniden yazılan metinde kaderciliğe dönüşmesidir. 1818 metnindeki “disgusted” sözcügüünün gösterdiği üzere, hocasının anlattığı dersi anlaşılmaz bulan Frankenstein doğa bilimlerinden "tiksinir" ve ilgi alanını kendi iradesiyle değiştirir. 1831 metninde ise onu doğa bilimlerinden uzaklaştıran, dolayısıyla da trajedilerinin kaynağı olan ucubeyi yaratmaya iten şey kendi özgür iradesi değil, kaderin ta kendisidir. Örnekte vurgulanan "by one of those caprices of the mind" (bir anlik hevesle), "miraculous change", (mucizevi değişim), "destiny" (kader) ve "her immutable laws" (onun değişmez yasaları) gibi ifadeler bu kaderci yaklaşımın altını çizmektedir.

\begin{tabular}{|c|c|}
\hline \multicolumn{2}{|l|}{ Örnek 13} \\
\hline 1818 (syf. 28) & 1831 (syf. 45) \\
\hline $\begin{array}{l}\text { The next morning I delivered my } \\
\text { letters of introduction, and paid } \\
\text { a visit to some of the principal } \\
\text { professors, and among others to } \\
\text { M. Krempe, professor of natural } \\
\text { philosophy. }\end{array}$ & $\begin{array}{l}\text { The next morning I delivered my letters of introduction and paid a } \\
\text { visit to some of the principal professors. Chance-or rather the evil } \\
\text { influence, the Angel of Destruction, which asserted omnipotent } \\
\text { sway over me from the moment I turned my reluctant steps from } \\
\text { my father's door-led me first to M. Krempe, professor of natural } \\
\text { philosophy. }\end{array}$ \\
\hline
\end{tabular}

Benzer şekilde bu örnekte de 1818 ve 1831 metinleri arasındaki özgür irade-kadercilik farkı görülmektedir. 1818 metninde Frankenstein'ın M. Krempe ile tanışması kendi bilinçli seçimidir; hocalarıyla tanışmak için onları ziyarete giden Frankenstein'ın ta kendisidir. Shelley 1818 metnindeki anlatıma 1831 metninde "Chance - or rather the evil influence, the Angel of Destruction (...) led me first to M. Krempe" cümlesini eklemiştir. Buna göre Frankenstein 1831 metninde de hocalarını ziyaret eder; ancak onu "ilk önce" M. Krempe'nin kapısına "götüren" şey, "talih" denen "yıkım meleği"dir. 


\begin{tabular}{|l|l|}
\hline \multicolumn{2}{|l|}{ Örnek 14 } \\
\hline $\mathbf{1 8 1 8}$ (syf. 30) & $\mathbf{1 8 3 1}$ (syf. 48) \\
\hline $\begin{array}{l}\text { I departed highly pleased with the } \\
\text { professor and his lecture, and paid } \\
\text { him a visit the same evening. His } \\
\text { manners in private were even more } \\
\text { mild and attractive than in public; } \\
\text { for there was a certain dignity in } \\
\text { his mien during his lecture, which } \\
\text { in his own house was replaced by } \\
\text { of fate, enounced to destroy me. As he went on, I felt as if my soul } \\
\text { were grappling with a palpable enemy; one by one the various keys } \\
\text { were touched which formed the mechanism of my being: chord after } \\
\text { chord was sounded, and soon my mind was filled with one thought, one } \\
\text { conception, one purpose. So much has been done, exclaimed the soul } \\
\text { of Frankenstein - more, far more, will I achieve: treading in the steps } \\
\text { already marked, I will pioneer a new way, explore unknown powers, } \\
\text { and unfold to the world the deepest mysteries of creation. }\end{array}$ \\
\hline
\end{tabular}

1818 metninde hocasının tavırlarından ve sözlerinden etkilenen Frankenstein, 1831 metninde hocasının bu sözlerini "kaderin sözleri” olarak yorumlamaktadır. Bu açıdan değerlendirildiğinde Frankenstein'1 "bilinmez güçleri keşfetmeye" ve "dünyanın en gizli yaratı gizemlerini ortaya çıkarmaya" teşvik eden, en sonunda da yıkımına neden olan yine "kaderin sözleri"dir. 1818 metnindeki özgür iradenin 1831 metninde yeniden yazılıp kaderciliğe dönüşmesi dikkat çekicidir. 1818 metnindeki Victor Frankenstein özgür iradesiyle kararlar alan ve bunları uygulayan bir adamdır; yaşadığı trajedi kendi iradesiyle aldığı kararların sonucudur. Fakat 1831 metnindeki Victor'un aklına bir canavar yaratma fikrinin düşmesi kaderin bir oyunudur. Dolayısıyla bundan sonra yaşanacak tüm trajik olaylar kaçınılmazdır; bütün bunların suçlusu da Victor'un kara talihidir. Bu örnekler bize 1818 metnindeki özgür iradenin yeniden yazılan 1831 metninde kaderciliğe dönüştüğünü gösterir.

Yaşam öyküsünü göz önüne alırsak, Mary Shelley'nin 1831'de kaderci bir tavır takınmasının nedenini yaşadığı trajik olaylarda bulmak mümkündür. Çocuklarını ve eşini birer birer kaybeden Shelley özgür iradenin insan yaşamına bir noktaya kadar etki ettiğine, kaderden kaçılamadığına inanmış olabilir. Shelley’e göre, yeniden yazılan metindeki Frankenstein da tıpkı kendisi gibi kaderin bir kurbanıdır. Ayrıca Mary Shelley 1831 metninin başında, genç bir kızın Frankenstein kitabında işlenen türden böylesine korkunç bir fikri nasıl düşünebildiği sorusuna ${ }^{7}$ cevap vermeye çalıştığ1 "Giriş" yazısında, içine doğduğu ailenin ve daha sonra hayatına giren Percy Shelley'nin kendisini bir şekilde yazmaya mecbur hissettirdiğinden söz eder. Aynı yazıda Frankenstein'ın Lord Byron'ın evindeki yazım öyküsünü de büyülü tesadüflerden ibaret, şans eseri bir durummuş gibi anlatır; yani bir bakıma Frankenstein Shelley’i bu metni kaderin bir eseridir; Mary Shelley de tıpk1 1831 metninde yeniden yazdığı Victor Frankenstein gibi kaderin kendisine çizdiği yolu izlemiştir.

\section{Sonuç}

Bu çalışmada dört tema bağlamında ele aldığımız on dört örneği Mary Shelley’nin yaşam öyküsü ve dönemin toplumsal şartlarını da göz önüne alarak yorumladığımızda, yazarın

7 "How I, then a young girl, came to think of, and to dilate upon, so very hideous an idea?" (Shelley, 1831 [2008]: 5). 
iddiasının ${ }^{8}$ aksine, 1818 metninin 1831 'de dikkat çekici bir biçimde yeniden yazıldığını gördük. Yeniden yazılmış metinde özellikle aile ve kadın imgelerinin yazarın daha önce sahip olduğu özgürlükçü anlayıştan uzak, toplumun muhafazakâr ideolojisine daha yakın bir biçimde kurgulandığını ortaya koymaya çalıştık. Erkek imgesi de dönemin toplumsal değerlerinin çizdiği erkek imgesine uygun bir biçimde yeniden yazılmış olsa da bu yeniden yazımın örtük bir toplumsal eleştiri olarak okunabileceğini söyleyebiliriz. Dolayısıyla kadın imgesinin bu denli edilginleştirilmesi ilk bakışta antifeminist bir yaklaşım gibi görünse de büyük hırslar peşinde koşan erkeklerin başarısızlığa mahkum edilmesiyle bu yeniden yazımın kadın ve erkek arasındaki firsat eşitsizliğinin altını çizmektedir. 1818 metninde hissedilen özgür irade anlayışının 1831 metninde kaderciliğe dönüştürülerek yeniden yazılması ise yazarın yaşam öyküsü bağlamında yorumlanarak değerlendirilmiştir.

Yeniden yazım kavramını çeviribilim alanında da tartışılan bir kavram haline getiren André Lefevere'in Translation, Rewriting, and the Manipulation of Literary Fame başlıklı çalışmasında uyguladığı inceleme yöntemi ışığında biz de yeniden yazım kavramını farklı boyutlarıyla ele almayı amaçladık. Bu nedenle, beş farklı başlık altında topladığımız yeniden yazım türleri içinde örnek olabilecek eser sayısı az olduğu için araştırma alanında yeterince irdelenmemiş olanına, bir metnin aynı yazar tarafından yeniden yazımına odaklanarak araştırmamızı geliştirdik. Bu çalışmada, Frankenstein eserinin 1818 ve 1831 versiyonları üzerinde yaptığımız karşılaştırmalı inceleme (yeniden) yazarın yaşam öyküsündeki ve ideolojisindeki değişikliklerin sözcük seçimi gibi tematik farklılıklar yaratan metinsel öğelere yansıyarak metnin bağlamını ve söylemini de yeniden yazabileceğini gösterdi. Dolayısıyla yeniden yazım kavramını sorgulayan bu çalışma metinsel incelemeyi ve tematik bir söylem çözümlemesini gerektirmiştir.

Bu sorgulama doğal olarak daha başka tartışmaları da beraberinde getirmektedir: Frankenstein örneğinde dönemin hangi toplumsal ve tarihsel koşulları/olayları Shelley'deki bu ideolojik değişime neden olmuştur? Aynı yazarın farklı dönemlerdeki yeniden yazımlarını her zaman toplumsal koşullardaki, yazarın yaşam öyküsündeki ve/veya ideolojisindeki değişiklikler mi belirler? Bu değişiklikler yeniden yazılmış metne ne şekilde yansır? Bu sorulara genel bir yanıt bulabilmek için farklı yeniden yazım örnekleri incelemenin de önemli olduğunu belirtmek gerekir.

Öte yandan çeviribilimin başka disiplinlerle etkileşimini bir kez daha vurgulayan bu çalışmanın ortaya çıkardığı bir diğer soru şudur: Yeniden yazım, metinlerarasılık (intertextuality), metinselaşkınlık (hypertextuality), dillerarası çeviri (interlingual translation), uyarlama (adaptation) gibi kavramlarla ilişkilendirilebilirken, bir metnin aynı yazar tarafindan yeniden yazımı hangi kavramları öne çıkarır? İncelediğimiz Frankenstein örneğini düşünürsek, bir imge

8 "I will add but one word as to the alterations I have made. They are principally those of style. I have changed no portion of the story, nor introduced any new ideas or circumstances. I have mended the language where it was so bald as to interfere with the interest of the narrative; and these changes occur almost exclusively in the beginning of the first volume. Throughout they are entirely confined to such parts as are mere adjuncts to the story, leaving the core and substance of it untouched." (Shelley, 1831 [2008]: 10-11). 
kurgulama aracı (image construction tool) ya da bir ideolojileştirme işlemi (ideologization process) olarak görülebilecek böyle bir yeniden yazımı -yazarı, toplumu ve dönemi de göz önünde bulundurarak- "yazarın imgesinin yeniden yazımı" (rewriting of the authorial image) olarak değerlendirmek mümkündür. Lefevere'in belirttiği gibi (1992: 5), yeniden yazımlar bir yazara, esere, döneme, türe, hatta bazen tüm edebiyata ilişkin imgeler yaratır; ait oldukları gerçekliklerle yan yana varlıklarını sürdüren bu imgeler gerçekliklere (yani metnin ilk yazımına) kıyasla daha çok insana ulaşır. Bu bakımdan Frankenstein'ın 1831'deki yeniden yazımı, Mary Shelley’nin “yazar imgesinin yeniden yazımı” olarak değerlendirilebilir. Shelley'nin kendi imgesini yeniden yazdığı bu metnin (1831) günümüzde hem kaynak hem de erek dizgelerde orijinal metin olarak benimsenmesi şaşırtıcı değildir. Dolayısıyla da, diyebiliriz ki, imgelerin dinamiği sayesinde gerçeklik (reality) olarak kabul edilen daha çok "yeniden yazım" ve "yeniden yazılmış yazar imgesi” olmuştur.

Hakem Değerlendirmesi: Dış bağımsız.

Çıkar Çatışması: Yazarlar çıkar çatışması bildirmemiştir.

Finansal Destek: Yazarlar bu çalışma için finansal destek almadığını beyan etmiştir.

Peer-review: Externally peer-reviewed.

Conflict of Interest: The authors have no conflict of interest to declare.

Grant Support: The authors declared that this study has received no financial support.

\section{KAYNAKÇA/REFERENCES}

Ackroyd, P. (2008). The casebook of Victor Frankenstein. London: Vintage.

Aktulum, K. (2000). Metinlerarasiililişkiler. İstanbul: Öteki Yayınları.

Barthes, R. (1981). "Theory of the Text", Robert Young (ed.) Untying the Text: A Post-Structuralist Reader içinde (ss. 31-47). London: Routledge and Kegan Paul.

Birkan-Baydan, E. (2011). Editing as rewriting. IUU Çeviribilim Dergisi 3(1), 55-79.

Genette, G. (1997). Palimpsests. Lincoln: University of Nebraska Press.

Hermans, T. (2009). Translation in Systems: Descriptive and Systemic Approaches Explained. Manchester: St. Jerome.

Jakobson, R. (2008). Çevirinin Dil(bilimsel) Özellikleri Üzerine (Çev. Ömer B. Albayrak), Mehmet Rifat (haz.), Çeviri Seçkisi II Çeviri(bilim) Nedir? içinde (ss. 61-66). İstanbul: Sel Yayıncılık.

Kristeva, J. (1980). “Word, Dialogue and Novel”, L. S. Roudiez (ed.), Desire in Language: A Semiotic Approach to Literature and Art içinde (ss. 64-91). New York, NY: Colombia University Press.

Lefevere, A. (1992). Translation, rewriting, and the manipulation of literary fame. London: Routledge.

Mellor, A. K. (1988). "In Search of a Family.” Mary Shelley, Her Life, Her Fiction, Her Monsters içinde (ss. 1-37). New York: Methuen.

Murray, E. B. (1981). Changes in the 1823 Edition of Frankenstein. The Library, 6th Series, 3, 320-7. 
Poovey, M. (1984). “"My Hideous Progeny': The Lady and the Monster.” The Proper Lady and the Woman Writer: Ideology as Style in the Works of Mary Wollstonecraft, Mary Shelley, and Jane Austen içinde (ss. 114-142). Chicago: University of Chicago.

Robinson, C. (2016). "Frankenstein.” A. Smith (ed.), The Cambridge Companion to Frankenstein içinde (ss. 13-25). Cambridge: Cambridge University Press.

Shelley, M. (1818 [2019]). Frankenstein 1818 Text. Nick Groom (ed.) Oxford University Press: New York.

Shelley, M. (1831 [2008]). Frankenstein. Joseph M. K. (ed.) Oxford University Press: New York.

Tymoczko, M. (1999). Translation in a Postcolonial Context: Early Irish Literature in English Translation. Manchester: St. Jerome.

Venuti, L. (2008). The Translator's Invisibility: A History of Translation. $2^{\text {nd }}$ ed. London: Routledge.

Venuti, L. (2012). “How to Read a Translation”, Translation Changes Everything içinde (ss. 109-115). Abingdon, Oxon: Routledge. 